\title{
Three Decades Monitoring of Shoreline Change Pattern of Damietta Promontory, Nile Delta, Egypt
}

\author{
Ayman A. El-Gamal (Corresponding author) \\ Marine Geology Department, Coastal Research Institute, National Water Research \\ Center, El-Shallalat, Postal code 21514, Alexandria, Egypt. \\ E-mail: ayman_elgamal@yahoo.com
}

\begin{abstract}
Sherif H. Balbaa
Marine Geology Department, Coastal Research Institute, National Water Research Center, El-Shallalat, Postal code 21514, Alexandria, Egypt.

E-mail: sherifbalbaa09@gmail.com
\end{abstract}

Mohamed A. Rashed

Geology Department, Faculty of Science, Alexandria University, Baghdad street, Moharam Bek, Alexandria, Egypt. E-mail: rashedmohamed@yahoo.com

\section{Ahmed S. Mansour}

Geology Department, Faculty of Science, Alexandria University, Baghdad street, Moharam Bek, Alexandria, Egypt. E-mail: ah_sadek@hotmail.com

Received: Apr. 27, 2020 Accepted: May 21, 2020 Published: May 25, 2020

doi:10.5296/ast.v8i2.17087 URL: https://doi.org/10.5296/ast.v8i2.17087

\begin{abstract}
The Nile Delta is located on the Egyptian Mediterranean coast extending along nearly 240 $\mathrm{km}$ from the east of Alexandria to Port Said. The coastal area of the Nile Delta Promontories has been suffering extensive erosion problem. This was achieved after the construction of many water regulation structures in Nile River as dams and barrages, particularly the Aswan High Dam. It has nearly stopped the sediment flux carried by the Nile River to the Delta. This process has caused the Mediterranean Sea to reshape the Nile Delta coastal area. In order to cease these problems several engineering hard structures have been built. These structures avoided in ceasing the problem in the site of construction but shifted the erosion problem to
\end{abstract}


the adjacent sites. This study aimed to analyze the shoreline change pattern on the term of three decades during the period between 1985 to 2015 at the coastal strip of Damietta Promontory and the impact of these protective structures on the coastal area. This was accomplished by the automated delineation of the successive shorelines covering this period using remote sensing imagery. The shorelines were extracted using the MNDWI index. The extracted shorelines were manipulated through the Digital Shoreline Analysis System (DSAS) software. The shoreline change rates were compared with sediments grain size for the past thirty years, heavy minerals content and radioactivity of recent marine sediment samples collected from different locations of marine profiles over the study area. The study revealed that Damietta Promontory has suffered from erosion during the study period reached its maximum shoreline retreat at the eastern side, nearly $-43 \mathrm{~m} / \mathrm{y}$. The total cumulative shoreline regression during the study period at this area was $1311 \mathrm{~m}$. The relation between the shoreline change process (erosion or accretion) and the physical parameters of coastal sediment showed that; as erosion increases, the heavy minerals content and radioactivity increases, while the mean grain size decreases and vice versa.

Keywords: remote sensing, coastal area changes, grain size, heavy minerals, radioactivity

\section{Introduction}

The Nile Delta is very densely populated and full of agriculture, industry and fishing activities and is of great importance to the Egyptian economy. The Nile Delta is one of the oldest deltaic systems in the world formed since the Miocene (Nielsen, 1976). It is highly dynamic area. Different coastal processes take place on the Nile delta coasts, which led to erosion in some sections and accretion in other parts. Nile delta subsidence is considered as one of the coastal concerned problems. The shoreline changes across the Nile delta were induced by human activities, engineering structures mainly barrages and dams. These are Delta barrage in 1861, Assuit barrage in 1902, Esna barrage in 1908, Edfina barrage in 1950, Aswan Low Dam in 1902 and Aswan High Dam in 1964 (Ghoneim et al., 2015). The Aswan High Dam is estimated to block about $98 \%$ of the sediment load. This caused that nearly all of the sediment stays in Lake Nasser and upstream of the Dam while only few sediment including silt and clay pass to the downstream (Shalash, 1982). The effect of sediment trapping has been demonstrated in the erosion and accretion problem. Erosion has many environmental, social and economic adverse effects. The environment is affected through salt water intrusion that is enhanced by erosion. This could affect the habitat of many coastal plants due to the increase of water salinity. While, the socio-economic effects appears in the deterioration of recreation and touristic facilities, residential and industrial areas that is located at or near the coastal zone (Hanson \& Lindh, 1993). Various studies and theories have been conducted in order to understand the complete picture of the Nile delta coastal stability and variation. Many scientists analyses the historical maps from different points of view (UNESCO/UNDP, 1978; Sestini, 1989; Frihy et al., 1991; Frihy et al., 2003). They used satellite images to delineate shorelines (Smith and Abdel-Kader, 1988; Frihy \& Dewidar, 2003; Aly et al., 2012), calculated the shoreline change rates (Frihy et al., 2004; Dewidar and Frihy 2010; Deabes, 2017), studied the effect of hard structure on the orientation of Nile Delta shoreline (Frihy et al., 2003; Elsayed et al., 2005; Elsayed and Mahmoud, 2007; El Banna, 2007). 


\subsection{Study Area}

The Damietta Promontory lies at the north east of the Nile delta about $40 \mathrm{~km}$ west of Suez Canal breakwaters (Figure 1) and was developed by the sediments transported by the Damietta branch since the Holocene (Coutellier and Stanley, 1987). It protruded seawards by a distance of about 5-8 km within the period from 1800 to 1900 (Sestini, 1976). The maximum seaward growth was in 1912 mapped shoreline (Fanos, et al., 1992). A reversed state from accretion to erosion began around 1900 due to reduction in the sediment load carried by the Nile River to the Damietta Branch. Also, land subsidence and sea level rise was accounted for the coastline change at Damietta promontory. Different rates of erosions were calculated during different time spans. Between 1971 and 1990, a 10.4 m/year erosion rate was calculated at Damietta Promontory (Frihy and Komar, 1993), while, between 1984 and 1991, a 15 m/year erosion rate was recorded by White and El-Asmar (1999).

\subsection{Protective Structures}

A series of engineering protective measures have been constructed to mitigate the intensive erosion process. A jetty was constructed at the western side of Damietta Branch outlet in 1941 to reduce the deposition of drifted sediments (Fanos et al., 1995). Another jetty was built on the eastern side in 1976 to reduce shoaling at the Damietta Branch outlet. A concrete revetment was built at the southern end of the western jetty in 1963 to stop the coastal erosion, which afterwards was modified into a rubble revetment to a distance about 1200 meters with 3.5 meters height above sea level. In 1971, three concrete groins were constructed to the south of this revetment with interspaces filled with basalt (El Banna, 2007). Within the period from 1991 and 2002, eight detached breakwaters were established at the western side of Damietta promontory along $3.5 \mathrm{~km}$ on the shoreline, $4 \mathrm{~m}$ water depth and about 400 meters from shore line with 200 meters gap and 200 meters length to combat shore erosion (Frihy et al., 2003). They are 4 to 7 tons concrete blocks armor with 2.5 meters height above sea level. In 2000, a $6 \mathrm{~km}$ long seawall oriented E-W was constructed along the eastern side of the Damietta outlet using 4 - 7 ton dolos (Dewidar and Frihy, 2010). 


\section{Macrothink}

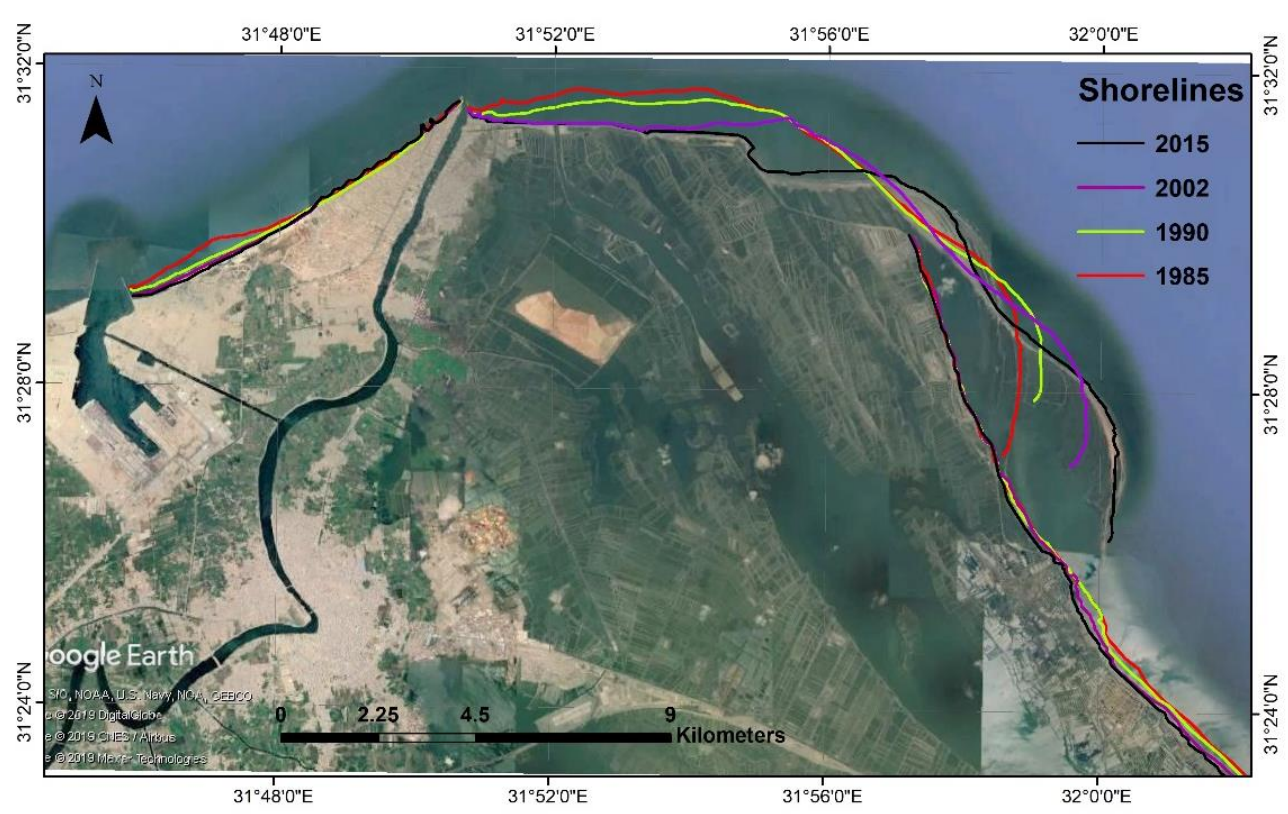

Figure1. The shoreline positions delineated from the Landsat images

In this study the Damietta promontory area was subdivided into three sectors; Sectors A, B, and C. Sector A extends for about $9 \mathrm{~km}$ between the western Jetty of Damietta Promontory and the eastern jetty of the Damietta Harbor entrance. Sector B covers a distance of about 17 $\mathrm{km}$ east of Damietta outlet including the spit area while sector $C$ extends for about $16.25 \mathrm{~km}$ from behind the Spit further to the east. Figure 2 shows the study area sectors and the cross-shore profiles from which the sediment samples were collected.

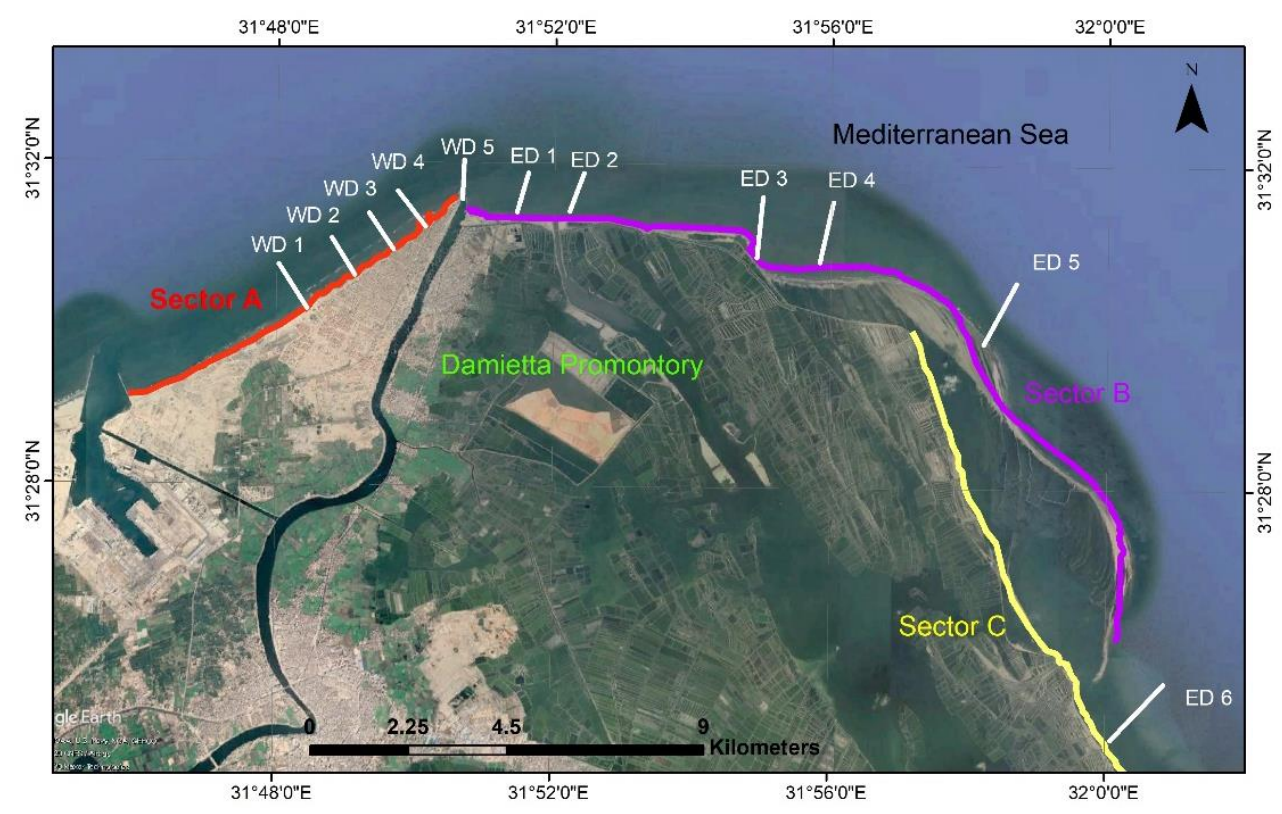

Figure 2. Study area sectors and the sediment cross-shore profiles

The objective of this study was to show the influence of the constructed protective structures on the coastal area. Also, to assess the relation between the coastal area alterations, mean grain size distribution, heavy minerals concentration and radioactivity in the sediment. 


\section{Materials and Methods}

\subsection{Shorelines Analysis Using Remote Sensing Data}

Images from Landsat including different sensors (MSS, TM, ETM+ and OLI) at unequal time intervals between 1985 and 2015 were used in this study. The shorelines were extracted using Erdas Imagine software. They were analyzed to delineate the shoreline positions (Figure 1) and its change rates during the study period. It was taken into consideration the effect of the cloud coverage and protective measures construction dates. The shorelines were extracted using the Modified Normalized Difference Water Index (MNDWI), which was proposed by $\mathrm{Xu}$ (2006). It is calculated by:

$$
\frac{\text { Green }-M I R}{\text { Green }+ \text { MIR }}
$$

Where GREEN is a band that encompasses reflected green light, while MIR is a middle infrared band. The MNDWI was chosen to be the best index for automated shoreline mapping based on its performance with comparison with other seven Landsat water indices (Kelly and Gontz, 2018). The rates of shoreline change were estimated using the Digital Shoreline Analysis software (DSAS). DSAS uses a measurement baseline method to calculate rate-of-change statistics for a time series of shorelines. The DSAS analysis was used to establish transect locations and calculate the related change statistics.

\subsection{Sedimentology}

A group of sediment samples was collected from a number of profiles across the Damietta Promontory. The sediment samples were analyzed for their mean grain size, heavy minerals concentration and radioactivity. The profiles were more or less perpendicular to the shoreline at different spacing as shown in figure 2. The profiles extend seaward to a 6 meters water depth or total profile distance of 1400 meters, which is closer. The sediment samples were collected by Van Veen Grap Sampler. The samples were washed by distilled water to remove salts and then dried to be ready for grain size analysis which is done either by sieve analysis or wet pipette analysis. To carry out sieving analysis, a representative dry sand sample of the sediment were fetched and run through a set of sieves at one-phi $(\phi)$ interval to segregate the sample into subset size classes and weighing the amount of material retained on each sieve. The $\phi$ value, was described by Krumbein, 1934, is calculated as following:

$$
\Phi=-\log _{2} D(\mathrm{~mm})
$$

where $\mathrm{D}$ is the grain diameter in millimeter.

For finer silt and clay grains, the wet pipette analysis method was conducted to determine the weight gradient of smaller grain diameters.

\subsection{Heavy Minerals Analysis and Radioactivity Measurement}

The heavy minerals in recent sediment samples are separated and weighted to determine its 
concentration in each sample. Bromoform was used in the present study by a procedure mentioned by Krumbein and Pettijohn (1938) and the finer fractions of each sample was obtained by sieving the sample and performing the separation on only $3 \phi$ and $4 \phi$ portions (Frihy and Lotfy, 1994). After the extraction of the heavy portion of minerals from the sediment samples, the concentration was calculated in weight percentages relative to the original weight of sample. The radioactivity was measured for each sample of the recent ones using survey meter model SEI USB Inspector. The device includes a Geiger-Muller (GM) tube to detect ionizing radiation. The device can count gross alpha, Beta, Gamma and X-ray radiation with an accuracy of $\pm 10 \%$. It was calibrated using a standard radioactive sources of Cs-137 and Co-60 (S. E. I, 2014).

\section{Results and Discussion}

\subsection{Shoreline Change Analysis}

The study has shown that the western sector of the Damietta Promontory (sector A) suffered from erosion at the eastern side of the Damietta Harbor at western jetty $(-17 \mathrm{~m} / \mathrm{y})$ as a result of the lack of sediment support from the west. This result is similar to the work of Deabes, (2017) and Mostafa, (2012) that may be due to lack of sediment support from the west. The sector suffered its highest erosion rate during the period between 1985 and 1990 (-66 m/y). This was before the construction of the eight detached breakwaters. The construction of the detached breakwaters has stopped the erosion and turned it to accretion behind them. The rate of accretion reached 10m/y between 1990 and 2002 that was confirmed in the work of El Banna, (2007). The average accretion rate at this sector was about $5 \mathrm{~m} / \mathrm{y}$ during the whole period of study (30 years) behind the detached breakwaters formed as salient, which also was confirmed by Deabes, (2017), while Mostafa, (2012) showed that the maximum rate of accretion was $10 \mathrm{~m} / \mathrm{y}$. So, the breakwaters have ceased the erosion at the whole sector except for the area near the eastern Damietta port jetty, which suffered erosion during the whole study period.

While sector (B) had shown greater variations as the average erosion rate reached about -43 $\mathrm{m} / \mathrm{y}$ at the revetment area this value of erosion was also confirmed by Dewidar and Frihy, 2010. While the average accretion rate of about $83 \mathrm{~m} / \mathrm{y}$ at the spit area. The erosion rate at the eastern promontory tip reached $-52 \mathrm{~m} / \mathrm{y}$ between 1985 and 2000, which is before the eastern seawall construction. After the seawall construction, the erosion rate at the tip had stopped, however the maximum erosion rate at the sector was recorded between 2002 and 2015, which reached about $-101 \mathrm{~m} / \mathrm{y}$ at the down drift of the constructed seawall. While the maximum accretion rate was estimated to be around 122 m/y between 1985 and 2000 at the Damietta spit due to the sediment that was carried by the littoral current from the promontory tip to the spit area. During the whole period of study, the spit has shown a south eastward movement and enlargement due to the continuous supply of sediment coming from the promontory tip before the seawall construction and the lee side of the seawall after its construction. These values of change rates and the effect of the constructions are similar to the results of Mostafa, 2012.

Sector $(\mathrm{C})$ of the Damietta Promontory showed the least variations in erosion and accretion 
patterns, which may be due to its natural protection by the Damietta Spit. This sector could be considered stable till the end of the spit. The average erosion rate estimated during 30 years was about $-13.9 \mathrm{~m} / \mathrm{y}$ at the area south of the spit. The work of Mostafa, 2012, also showed comparable results at this sector of the study area.

\subsection{Mean Grain Size Analysis}

The grain size distribution among the study area showed great variations between one profile to another. As an overall distribution, the grain size showed a fining trend towards the promontory outlet. Also, it showed a fining trend towards the offshore. The common values of mean grain size among the study area ranged from around very fine sand (5.7 $\Phi)$ to coarse sand $(1.4 \Phi)$. According to the present study, grain sizes at the coastal strips of Damietta Promontory showed a relation with the shoreline change rate estimated. The mean grain size values showed a fining trend at the erosional coastal strips as those appeared in the profiles WD 1 that is in the downdrift side of the Damietta Port. While, coarsening trend appeared in profiles at advancing coastal strips as WD2, WD 3 and WD 4 that are behind the detached breakwaters at the western side of Damietta Promontory and ED 4 and ED 5 that lies in the accretionary Damietta sand spit.

\subsection{Heavy Minerals and Radioactivity}

On the other hand, the heavy minerals concentrations show spatial variation along the study area and show a pattern relative to the shoreline change. It is obvious that the heavy minerals are enriched in coastal strips that suffered erosion (as the promontory tips). It relatively decreases in areas of accretion. By comparing the heavy minerals concentrations at each sample with the mean grain size value, radioactivity and shoreline change pattern, it appeared that there is a relation among them. Erosional beaches showed a fining trend in mean grain size, an increase in the heavy minerals' concentration and radioactivity and vice versa. This pattern is due to the selective removal for the light minerals that is relatively coarser in grain size (as quartz and feldspar) and delivering them to the accretionary beaches leaving behind the finer denser heavy minerals increasing it concentration. This effect was mentioned in the work of Frihy and Lotfy, 1994, El-Asmar \& White, 2002 and El Banna, 2007. The composition of heavy minerals involves radioactive atoms that is responsible for the relative increase in the radioactive dose of those samples. 

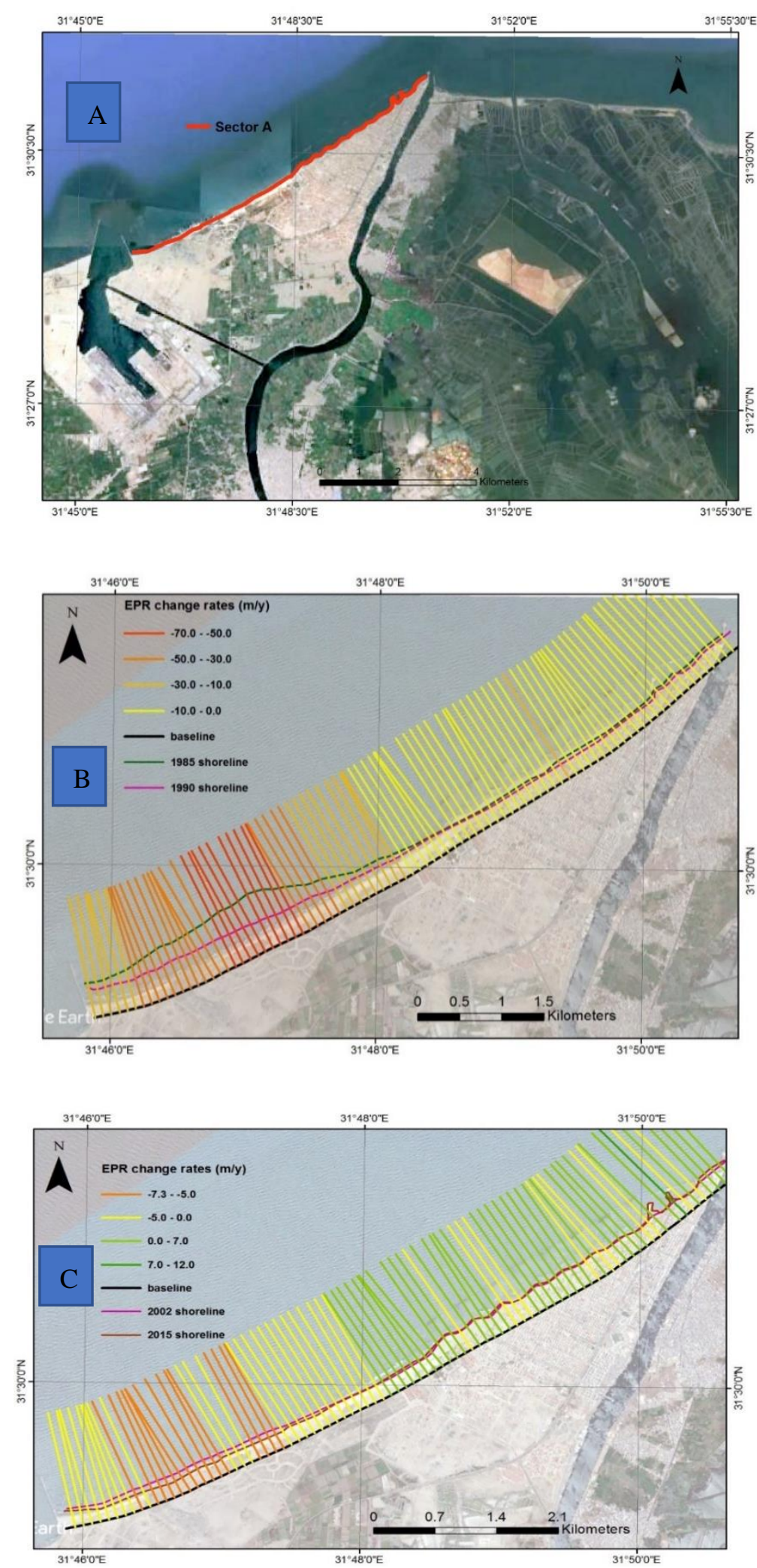

Figure 3. (A) shows the shoreline change analysis using DSAS at Sector A of the study area (B) between 1985 and 1990 and (C) between 2002 and 2015 

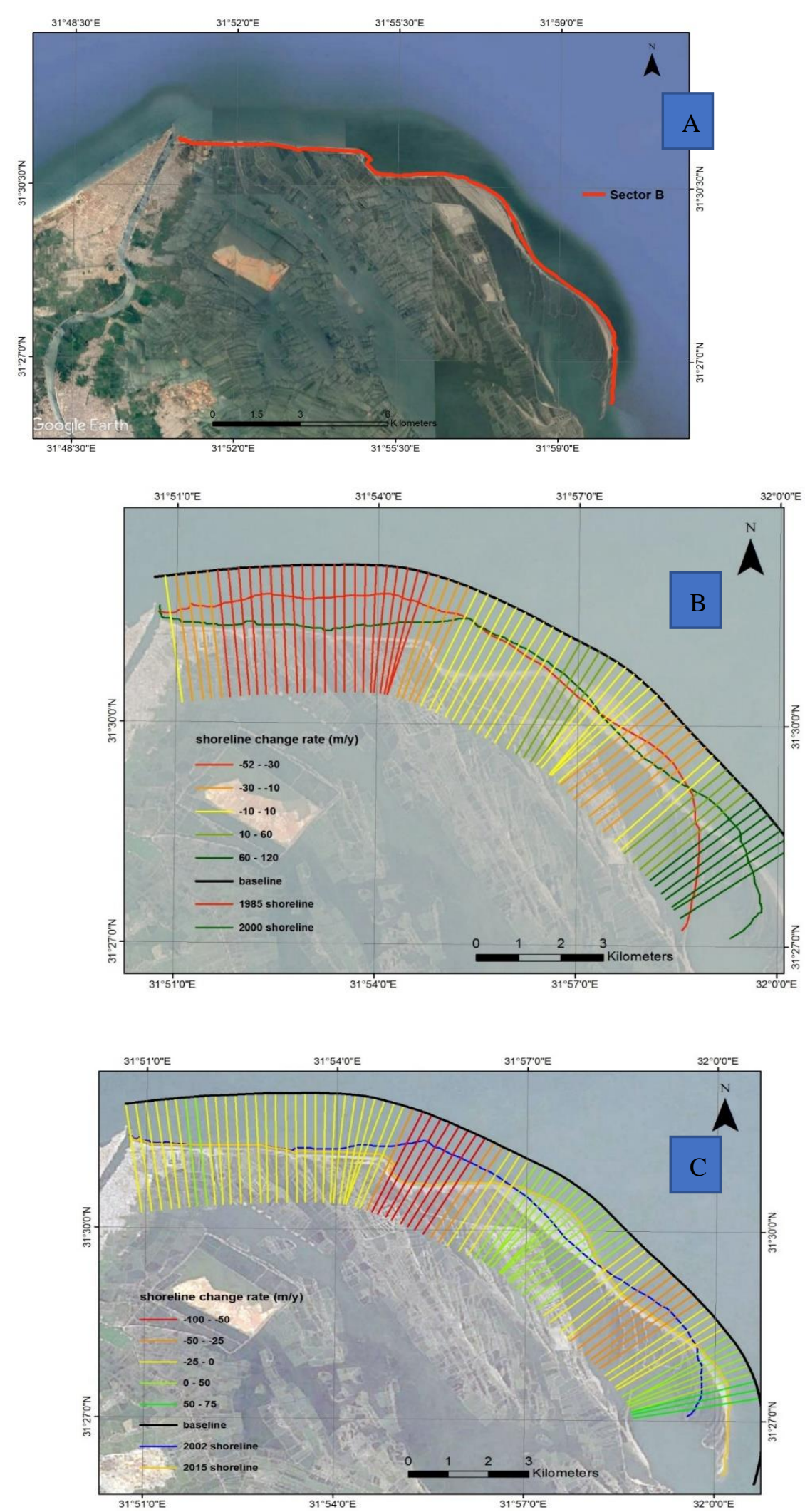

Figure 4. (A) shows the shoreline change analysis using DSAS at Sector B of the study area (B) between 1985 and 2000 and (C) between 2002 and 2015 

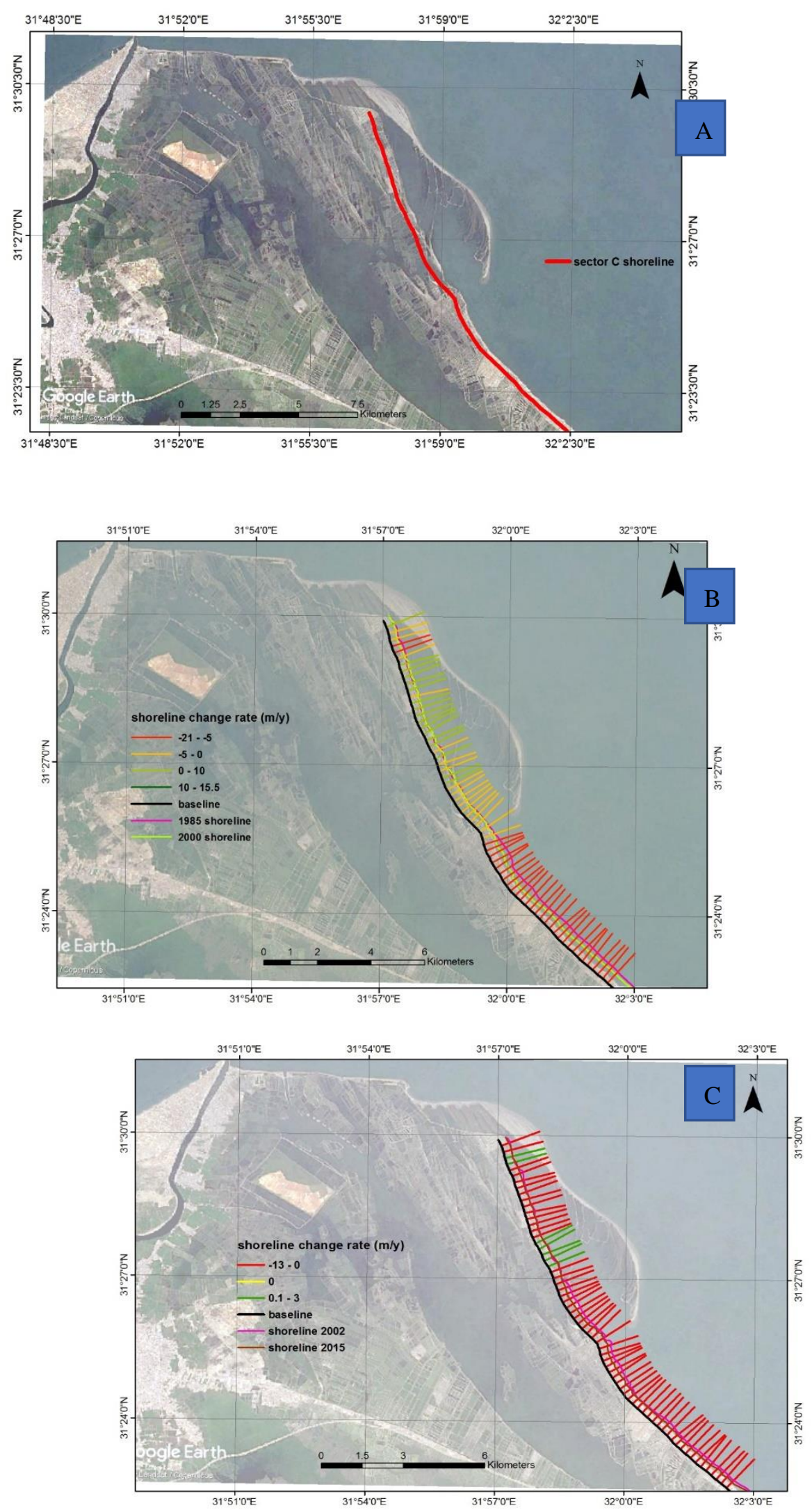

Figure 5. (A) shows the shoreline change analysis using DSAS at Sector C of the study area (B) between 1985 and 2000 and (C) between 2002 and 2015 

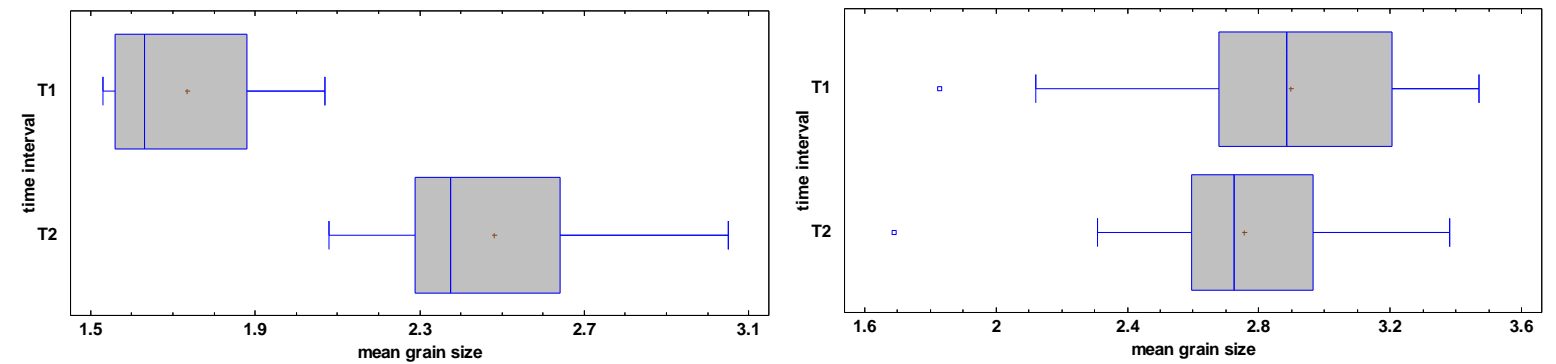

WD 3

WD 4
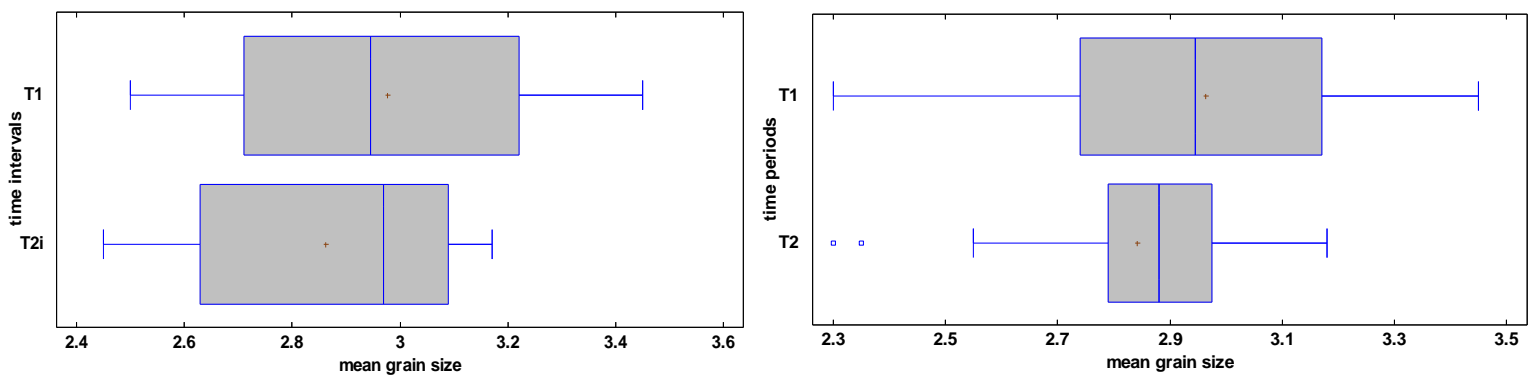

Figure 6. Box and Whisker plots for west Damietta Promontory profiles mean grain size at different time spans (T1 between 1985 and 2002 and T2 between 2002 and 2015)

East Damietta Profiles

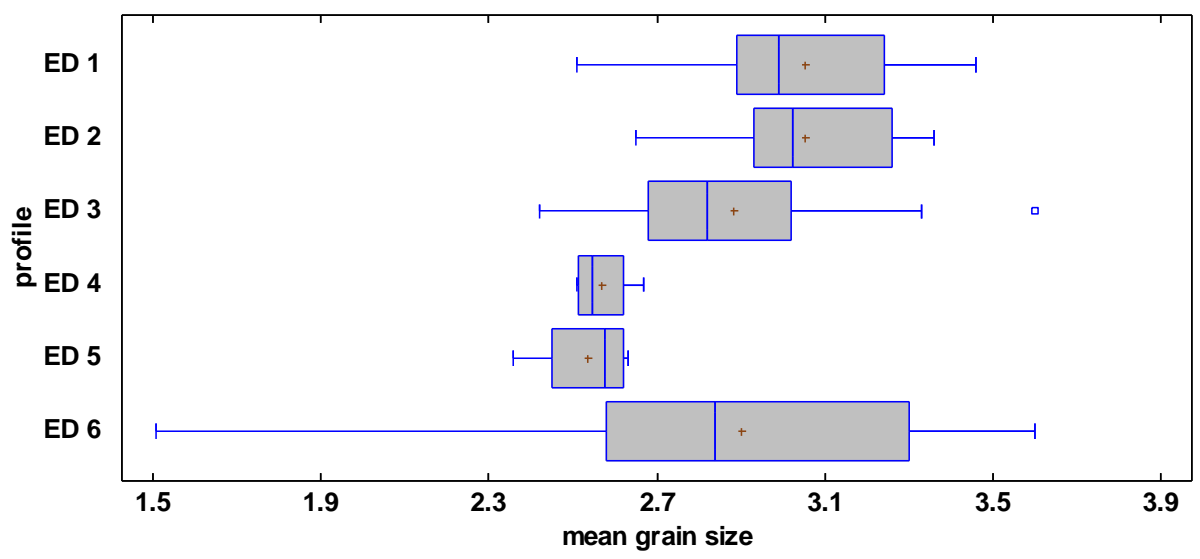

Figure 7. Box and Whisker plot for the mean grain size of the Eastern Damietta Profiles

\section{Conclusion}

1- Concerning Damietta Promontory shoreline change, Sector (B) has shown the extremes of variation of both erosion and accretion. The maximum erosion rate reached about $-101 \mathrm{~m} / \mathrm{y}$ between 2002 and 2015, which was at the down drift of the 
constructed seawall. On the other hand, the maximum accretion rate was estimated to be about $122 \mathrm{~m} / \mathrm{y}$ between 1985 and 2000 at the Damietta spit due to the sediment that was carried by the littoral current from the promontory tip to the spit area.

2- The implementation of the protective measures on shoreline is only beneficial regarding the protection of the site of construction and translocate the problem to the adjacent areas at the two terminals.

3- The mean grain size is inversely related with the rate of erosion as the rate of erosion increase the mean grain size decreases at beaches.

4- The concentration of heavy minerals and amount of radioactivity is directly proportional with the rate of erosion as it increases with the erosion rate increases.

\section{Recommendations}

The coastal protection using hard structures is not the final process to mitigate the erosion at coasts. So, it is recommended to study the effect of environmental soft structure for coastal protection (as sand nourishment and protective dunes) instead of hard structure or using both of them together. Also, further study of the effect of each protective structure on the short and long term, assess its role in stabilizing the shoreline, and study its negative impact on the neighborhood coastal area and its impact on the water quality and aquatic habitat. It is recommended to study different physical parameters of sediment (as magnetic property for example) as a new approach to distinguish between sediment from erosional or accretional beaches.

\section{References}

Aly, M. H., Giardino, J. R., Klein, A. G., \& Zebker, H. A. (2012). InSAR study of shoreline change along the Damietta Promontory, Egypt. Journal of Coastal Research, 284(May), 1263-1269. https://doi.org/10.2112/JCOASTRES-D-11-00182.1

Coutellier, V., \& Stanley, D. J. (1987). Late Quaternary stratigraphy and paleogeography of the eastern Nile Delta, Egypt. Marine Geology, 77(3), 257-275. https://doi.org/https://doi.org/10.1016/0025-3227(87)90116-2

Deabes, E. (2017). Applying ArcGIS to Estimate the Rates of Shoreline and Back-Shore Area Changes along the Nile Delta Coast , Egypt. International Journal of Geosciences, 8, 332-348. https://doi.org/10.4236/ijg.2017.83017

Dewidar, K. M., \& Frihy, O. E. (2010). Automated techniques for quantification of beach change rates using Landsat series along the North-eastern Nile Delta, Egypt. Journal of Oceanography and Marine Science, 1, 28-39.

El Banna, M. M. (2007). Erosion and accretion rates and their associated sediment characters along Ras El Bar coast, northeast Nile Delta, Egypt. Environmental Geology, 52(1), 41-49. https://doi.org/10.1007/s00254-006-0447-2

El-Asmar, H. M., \& White, K. (2002). Changes in coastal sediment transport processes due to 
construction of New Damietta Harbour, Nile Delta, Egypt. Coastal Engineering, 46, 127.

Elsayed, M. A. K., \& Mahmoud, S. (2007). Groins system for shoreline stabilization on the east side of the Rosetta Promontory, Nile Delta coast. Journal of Coastal Research, 23(2), 380-387. https://doi.org/10.2112/04-0319.1

Elsayed, M. A. K., Younan, N. A., Fanos, A. M., \& Baghdady, K. H. (2005). Accretion and erosion patterns along Rosetta Promontory, Nile Delta Coast. Journal of Coastal Research, $21((3)), 412$.

Fanos, A. M., Khafagy, A. A., \& Dean, R. G. (1995). Protective works on the Nile Delta coast. Journal of Coastal Research, 11(2), 516-528.

Fanos, A. M., Khafagy, A. A., \& Komar, P. D. (1992). Erosion of the Damietta Promontory, the Nile Delta. Coastal Engineering, 3246-3259.

Frihy, O. E., \& Dewidar, K. M. (2003). Patterns of erosion/sedimentation, heavy mineral concentration and grain size to interpret boundaries of littoral sub-cells of the Nile Delta, Egypt. Marine Geology, 199, 27.

Frihy, O. E., \& Komar, P. D. (1993). Long-term shoreline changes and the concentration of heavy minerals in beach sands of the Nile Delta, Egypt. In Marine Geology (Vol. 115). https://doi.org/10.1016/0025-3227(93)90054-Y

Frihy, O. E., \& Lotfy, M. F. (1994). Mineralogy and textures of beach sands in relation to erosion and accretion along the Rosetta Promontory of the Nile Delta , Egypt. Journal of Coastal Research, 10(3), 588-599.

Frihy, O. E., Debes, E. A., \& El Sayed, W. R. (2003). Processes reshaping the Nile delta promontories of Egypt: pre- and post-protection. Journal of Geomorphology, 53(3), 263-279. https://doi.org/10.1016/S0169-555X(02)00318-5

Frihy, O. E., El Banna, M. M., \& El Kolfat, A. I. (2004). Environmental impacts of Baltim and Ras El Bar shore-parallel breakwater systems on the Nile delta littoral zone, Egypt. Environmental Geology, 45(3), 381-390. https://doi.org/10.1007/s00254-003-0886-y

Frihy, O. E., Fanos, A. M., Khafagy, A. A., \& Komar, P. D. (1991). Nearshore sediment transport patterns along the Nile Delta Egypt. Journal of Coastal Engineering, 15, 409.

Ghoneim, E., Mashaly, J., Gamble, D., Halls, J., \& AbuBakr, M. (2015). Nile Delta exhibited a spatial reversal in the rates of shoreline retreat on the Rosetta promontory comparing preand post-beach protection. Geomorphology, 228, 1-14. https://doi.org/10.1016/j.geomorph.2014.08.021

Hanson, H., \& Lindh, G. (1993). Coastal Erosion: An Escalating Environmental Threat. Ambio, 22(4), 188-195. http://www.jstor.org/stable/4314068

Kelly, J. T., \& Gontz, A. M. (2018). Using GPS-surveyed intertidal zones to determine the validity of shorelines automatically mapped by Landsat water indices. International Journal of Applied Earth Observation and Geoinformation, 65, 92-104. 
https://doi.org/10.1016/j.jag.2017.10.007

Krumbein, W. C. (1934). Size frequency distributions of sediments. Journal of Sedimentary Research, 4(2), 65-77. https://doi.org/10.1306/D4268EB9-2B26-11D7-8648000102C1865D

Krumbein, W. C., \& Pettijohn, F. J. (1938). Manual of sedimentary petrography. D. Applenton-Century Company.

Mostafa, A. T. T. (2012). Analysis and modeling of long-term shoreline changes and alongshore sediment characteristics on the Nile Delta Coast. The University of Tokyo.

Nielsen, E. (1976). Shore evolutions. Proc. Seminar Nile Delta Coastal Process, 15-59.

S. E. I. (2014). Inspector USB Manual.

Sestini, G. (1976). Geomorphology of the Nile Delta. Proceedings UNESCO Seminar on Nile Delta Sedimentology, 12-24.

Sestini, G. (1989). Nile Delta: A review of depositional environments and geological history. Geological Society, London, Special Publications, 41, 99-127. https://doi.org/10.1144/GSL.SP.1989.041.01.09

Shalash, S. (1982). Effects of sedimentation on the storage capacity of the High Aswan Dam reservoir. Hydrobiologia, 91, 623-639. https://doi.org/10.1007/BF00000061

Smith, E. S., \& Abdel-Kader, A. (1988). Coastal erosion along the Egyptian Delta. Journal of Coastal Research, 4(2), 245-255. http://www.jstor.org/stable/4297400\%0Ahttp://about.jstor.org/terms

UNESCO/UNDP. (1978). Coastal protection studies, final technical report.

White, K., \& El-Asmar, H. M. (1999). Monitoring changing position of coastlines using Thematic Mapper imagery, an example from the Nile Delta. Geomorphology, 29, 93.

Xu, H. (2006). Modification of Normalised Difference Water Index ( NDWI ) to enhance open water features in remotely sensed imagery. International Journal of Remote Sensing, 27(14), 3025-3033. https://doi.org/10.1080/01431160600589179

\section{Copyrights}

Copyright for this article is retained by the author(s), with first publication rights granted to the journal.

This is an open-access article distributed under the terms and conditions of the Creative Commons Attribution license (http://creativecommons.org/licenses/by/4.0/) 